\title{
Water Quality Improvement Policies: Lessons Learned from the Implementation of Proposition $O$ in Los Angeles, California
}

\author{
Mi-Hyun Park · Michael Stenstrom • \\ Stephanie Pincetl
}

Received: 28 July 2007/ Accepted: 17 December 2008/Published online: 29 January 2009

(c) The Author(s) 2009. This article is published with open access at Springerlink.com

\begin{abstract}
This article evaluates the implementation of Proposition O, a stormwater cleanup measure, in Los Angeles, California. The measure was intended to create new funding to help the city comply with the Total Maximum Daily Load requirements under the federal Clean Water Act. Funding water quality objectives through a bond measure was necessary because the city had insufficient revenues to deploy new projects in its budget. The bond initiative required a supermajority vote (two-thirds of the voters), hence the public had to be convinced that such funding both was necessary and would be effective. The bond act language included project solicitation from the public, as well as multiple benefit objectives. Accordingly,
\end{abstract}

M.-H. Park

Department of Civil and Environmental Engineering, College of Engineering, University of Massachusetts Amherst,

16D Marston Hall, 130 Natural Resources Road, Amherst, MA 01003, USA

e-mail: mpark@ecs.umass.edu

\section{Stenstrom}

Civil and Environmental Engineering Department, University of California, Los Angeles (UCLA), 5714 Boelter Hall, Los Angeles, CA 90095-1593, USA

e-mail: stenstro@seas.ucla.edu

S. Pincetl $(\bowtie)$

Institute of the Environment, University of California, Los Angeles (UCLA), LaKretz Hall, Suite 300, 619 Charles E.

Young Dr. East, Los Angeles, CA 90095-1496, USA

e-mail: spincetl@ioe.ucla.edu

S. Pincetl

Pacific Southwest Research Station, U.S. Forest Service, Riverside, USA nonprofit organizations mobilized to present projects that included creating new parks, using schoolyards for flood control and groundwater recharge, and replacing parking lots with permeable surfaces, among others. Yet few, if any, of these projects were retained for funding, as the city itself also had a list of priorities and higher technical expertise in justifying them as delivering water quality improvements. Our case study of the implementation of Proposition O points to the potentially different priorities for the renovation of urban infrastructure that are held by nonprofit organizations and city agencies and the importance of structuring public processes clearly so that there are no misimpressions about funding and implementation responsibilities that can lead to disillusionment with government, especially under conditions of fiscal constraints.

Keywords Proposition O - Clean Water Act .

Total Maximum Daily Load - Stormwater management . Water quality improvement - Fiscal constraints .

Participation

\section{Introduction}

With the passage of the National Environmental Policy Act (NEPA) and other environmental protection laws in the 1970s, public participation was formally integrated into rule making through public comment, and in their implementation by standing to sue if implementation was seen to violate the law. Public comment and standing to sue reflected a sea change that was occurring regarding the role of the state and its responsibility to act in a transparent and open manner that was more inclusive of the public. Perceived state failures to adequately regulate the environment 
created the push for these new regulations, and increased public participation was seen as improving the substantive and procedural quality of decisions (Beierly and Konisky 2000, p. 567). These developments have led to a sense that "public participation is ... considered an unalloyed good" (Rydin and Pennington 2000, p. 153). As a result, the drive to increase access and influence by the public and concerned nonprofit organizations in environmental policymaking has been a key component of many programs, from watershed management initiatives to forest management plans, including the funding of nonprofits to implement environmental programs.

In this case study, we examine a one-half-billiondollar storm-water bond initiative passed in 2004 by the voters of the City of Los Angeles that included solicitation of proposals for new infrastructure and projects from the public and a multiple-benefits approach to meeting the Total Maximum Daily Loads (TMDLs) for pollution established by the federal Clean Water Act (CWA), interpreted for local pollution conditions by the state Regional Water Quality Control Board (RWQCB). The bond itself was written through a consultative process that invited prominent environmental nonprofits and leaders in the environmental movement to author the proposition with city officials. The approach to the initiative was clearly a participatory stakeholder process, reflecting the perceived importance of including representatives of the public. Those invited represented interested and engaged stakeholders who had been adept at using the public participation language of the CWA to engage in local governmental processes. In fact, several of the invited organizations had been party to a lawsuit under the CWA to force the city to upgrade its stormwater quality.

In this article we discuss the geographical and political components involved in shaping environmental strategies, management policies, and programs in response to increasingly stringent water quality regulations in the city of Los Angeles. Through this case study, we show how tensions can arise when nonprofit organizations are invited to participate but government retains all the control, in contradistinction to the approach described above. For Los Angeles, like other jurisdictions in California, such tensions are important to understand, as raising new funding streams is difficult, requiring a two-thirds majority (supermajority) vote by the electorate. When nonprofit organizations feel excluded from decision making and implementation, and there is a perception that the process is not transparent-that is, that the city itself has an unrevealed agenda it is pushing through by controlling the process-the city jeopardizes its ability to enlist their support for additional, needed funding in the future.
Study Site: Los Angeles, a Complex Urban Setting

Size and Place

Los Angeles is a city of 4 million people, spanning $1215 \mathrm{~km}^{2}$ that includes steep mountains, coastal areas, and hot inland valleys. The Mediterranean climate can produce heavy seasonal rains and storm-water flow can amount to 38 billion liters a day into Santa Monica Bay in rainyweather days and 378 million liters a day in dry-weather days (Los Angeles Bureau of Sanitation, www.lastormwater.org/Siteorg/residents/whatis.htm). The city is downstream of steep and high mountains in national forests (up to $3 \mathrm{~km}$ ), and upland cities. Storm water carries with it nonpoint source pollution-urban detritus-that contaminates local waters and the ocean. Pollution includes bacteria, fecal coliform, heavy metals, nitrogen, and other pollutants (LADPW 2006). Treating this volume of storm water and dry-weather runoff is a fiscal and infrastructure construction near-impossibility, requiring different CWA compliance strategies than might be pursued in places with lower storm-water volumes and fewer surges. While there is a recently adopted Integrated Regional Water Management Plan (IRWMP) between the city and the county of Los Angeles, implementation costs and process remain problematic and there are no established mechanisms for cost-sharing.

\section{A Tax-Limited State}

In addition to the sheer size of the watersheds in which Los Angeles finds itself, and the natural climate conditions that pose engineering challenges to storm-water treatment, California is a tax-limited state. No new local taxes or bond measures can be implemented without a two-thirds majority vote. California is also one of three states that require a two-thirds majority vote to pass the state budget. This affects the funding for all programs at all levels—city, county, and state (Pincetl 1999; Shrag 1999).

Similar to many cities in the United States, the city of Los Angeles has been delinquent in its infrastructure repair. The American Society of Civil Engineers estimates that Los Angeles needs more than $\$ 30$ billion simply to perform required maintenance on its infrastructure, let alone meet new CWA requirements that necessitate new infrastructure. This situation suggests that for the city to comply with the requirements of the CWA, it needs a supermajority of voters to support additional taxes or fees.

What has been Done

There have now been various Best Management Practices (BMPs) implemented in Los Angeles. The cities of Los 
Angeles and Santa Monica are in the process of installing catch-basin inserts and covers to retain pollutants and trash (Lau and others 2001). Catch basins have been stenciled with the sign "No dumping-this drains to ocean" to inform the public, and the city has installed 38,000 catch-basin inserts. Low-flow diversions have been installed (Stenstrom 1999). The city and county of Los Angeles are also collaborating on a joint demonstration project in the Sun Valley area to manage storm-water runoff and flooding using schoolyards as spreading grounds among other BMPs, including afforestation (Higgins and Roth 2005). The Sun Valley flagship multiple-benefits storm-water project is a result of the charismatic leadership of the founder of one of the city's most prominent nonprofit organizations, TreePeople. Andy Lipkis was able to forge the city and county partnerships necessary for this experimental alternative to a conventional storm drain, and was one of the advocates for including multiple-benefits projects in the language of Proposition O.

In addition, the city and county of Los Angeles have several diversion systems that pump dry-weather flow from the storm drain into sanitary sewers and treatment plants. Santa Monica has built the Santa Monica Urban Runoff Recycling Facility (SMURRF) to treat dry weather runoff (Shapiro 2002). Thus, the city and county of Los Angeles and other cities in the county have been working to reduce storm-water runoff, integrating various approaches from structural BMPs and several land-use-based BMPs. including the unique Sun Valley project.

\section{Proposition O}

Proposition O-the Clean Water, Ocean, River, Beach, and Bay Storm-water Cleanup Measure-was approved overwhelmingly, by $76 \%$ of Los Angeles voters, in 2004 and authorized the city of Los Angeles to issue $\$ 500$ million in general bonds for storm-water projects to:

- Protect rivers, lakes, beaches, and the ocean

- Conserve and protect drinking water and other water sources

- Reduce flooding and use neighborhood parks to decrease polluted runoff and capture, clean up, and reuse storm water.

The Administrative Structure

Proposition $\mathrm{O}$ is administered by:

- A Citizens Oversight Advisory Committee (COAC)

- An Administrative Oversight Committee (AOC)
- The Watershed Protection Division (WPD) of the Bureau of Sanitation (BOS), located in the Department of Public Works

The COAC, representing the public, is composed of appointees. The mayor appoints four of the nine members, and the city council president appoints the others. Three must be experienced in clean water; one must be recommended by the Regional Water Quality Control Board, and others are to represent the public in general terms. The $\mathrm{COAC}$ is responsible for:

- Establishing the criteria for selection of projects, in collaboration with the Bureau of Sanitation

- Applying the criteria to projects

- Recommending projects for funding

- Establishing projects' funding levels

The COAC recommendations then go to the AOC, which represents the mayor's office. The AOC consists of:

- The city's Administrative Officer

- The Chief Legislative Analyst of the city

- A representative from the mayor's office

- One of the mayor-appointed commissioners from the Board of Public Works

- The General Manager of the Department of Water and Power

The AOC makes its determination and sends its recommendations to the city council, which makes the final determination about projects. When the COAC and the AOC have dissenting opinions, the AOC can override the COAC.

The WPD is the city agency responsible for managing and administering Proposition O. It is also responsible for compliance with the CWA. In addition, it is responsible for developing implementing storm-water pollution abatement projects throughout the city and for overseeing their construction. It therefore has a strong vested interest in Proposition O's success in storm-water quality improvement, as well as in the types of projects selected. WPD's current annual expenditures are $\$ 31$ million, amounting to about $\$ 1.91$ per month per household — an amount that has been frozen since 1991 .

\section{Public Participation}

The implementation of Proposition $\mathrm{O}$ included assistance to the public in writing proposals. This was provided by three large engineering firms under long-term contract with the Bureau of Sanitation, with the idea that the proposals would then be competitive for funding with those generated by governmental entities, including city departments. 
Approximately $\$ 190,000$ was spent for outreach and consulting services in the first year. Over 100 people attended workshops held at several locations throughout Los Angeles. In December 2005, the city received 50 project proposals by city agencies and community organizations. Among them, 22 projects were proposed by local environmental nonprofit organizations.

\section{The City Process}

The Proposition $\mathrm{O}$ bond initiative listed goals to achieve with no language to guide the implementation of the goals. The Proposition did not prioritize among the listed goals, there were no stated quantitative pollution-reduction targets, nor was there a framework for choosing projects. Nearly all the water bodies in the city are polluted, some are more polluted than others, and the watersheds of the streams and rivers differ greatly, but the proposition did not address any of these factors. Therefore, it fell to the COAC to develop an implementation process. This largely consisted in developing project-selection criteria. Although certain members of the COAC argued for the development of a plan for the implementation of the bond to ensure an orderly and clear process and set of priorities, the majority favored simply developing project selection criteria that could be applied to each proposal individually. Even the development of criteria, however, turned out to be a contentious process, as the proposition stated multiple goals and members of the COAC represented different interests and communities.

Community representatives on the COAC felt strongly that multiple benefits meant local open-space and greeningcommunity benefits, whereas water quality representatives felt that criteria should prioritize water quality and that criteria could not be well developed to evaluate multiple benefits, as multiple benefits are diffuse. The result was a nonrigorous, vague, and contradictory set of criteria. The Project Review Committee (PRC), created in December 2005 , then used the criteria to categorize each individual proposal.

The PRC was staffed by five different city agencies, including:

- The WPD (located in Public Works)

- The Bureau of Engineering (located in Public Works)

- The Department of Water and Power

- The Recreation and Parks Department

- The Environmental Affairs Department

COAC members and the public were invited to participate in a daylong session during which all the proposals were evaluated. The PRC, acutely aware of inconsistencies, errors, and other problems in the evaluation of the proposals they had received from the COAC, struggled through the session to assign the 50 proposed projects into the following three categories.

- Category A: Projects meeting Proposition O eligibility requirements and receiving high scores in the evaluation process

- Category B: Projects needing modifications in order to satisfy Proposition $\mathrm{O}$ eligibility requirements

- Category C: Projects not meeting Proposition O eligibility requirements

The PRC developed yet another category, B-2, for those projects needing further investigation, additional quantification information, and an additional concept report. It turns out that only a few of the projects proposed by nonprofits had the technical specificity needed to quantify water quality benefits. Additionally, most of the projects put forward by community nonprofit environmental organizations were multiple-benefits projects that included local green space benefits or other such improvements. The B-2 category was created because members of the COAC and the PRC did not want to seem to be excluding proposals generated by nonprofit environmental organizations.

The PRC selected 22 proposals, of which 59\% were city projects, $18 \%$ were from other municipalities and governmental entities, and 23\% were environmental nonprofit projects.

The multiple-benefit projects proposed by nonprofits encountered two problems.

1. The technical support provided by the consultant engineering firms had been inadequate to help craft well-developed proposals; there was not enough funding to do a complete job.

2. Because multiple benefits are difficult to quantify, the "soft" results promised by multiple-benefits proposals inevitably fell short of the results indicated in more traditionally formulated proposals.

Those environmental nonprofits whose projects were categorized as B-2 received more time to develop their proposals, but the technical calculations necessary to be competitive with traditional storm-water projects were beyond the expertise and fiscal capability of nearly all nonprofit organizations.

\section{Methods}

Our methods for this case study were both qualitative and quantitative. Qualitative methods included attending public participation and education meetings, monthly Proposition $\mathrm{O}$ meetings of the $\mathrm{COAC}$ and the $\mathrm{AOC}$, and numerous other Proposition $\mathrm{O}$ related meetings over nearly 2 years. We reviewed Proposition O- and CWA-related technical 
reports and news reports as well, and surveyed the literature on storm-water remediation and multiple-benefits approaches. The principal investigator also traveled to Baltimore to study the Watershed 263 program and conducted interviews with governmental, nonprofit, and university researchers about the structure of the program, funding, and roles and responsibilities.

Our quantitative method consisted of a survey. The survey questions were organized around two areas of inquiry:

1. The process of implementation

2. The criteria for selection of projects developed by the Citizens Oversight Advisory Committee (COAC)

We sent 80 questionnaires to the following:

- Selected COAC members representing each category of appointee

- All Project Review Committee members

- The three technical consultants who assisted applicants in preparing proposals

- Community activists who were present at nearly all the COAC meetings

- Community environmental nonprofit applicants

- Selected experts working on storm-water management from different sectors:

1. Professors

2. Researchers

3. Engineering consultants

4. City and government employees

Questionnaires were distributed to each group by mail and e-mail. The questions for each group were slightly different. We also interviewed eight representative individuals involved in the process. These included members from the COAC, from the governmental and nonprofit project applicants, citizen watchdog attendees at the COAC hearings and other related meetings, and members of the environmental nonprofit organizations involved in writing Proposition $\mathrm{O}$. We asked each of them the same questions as on the questionnaire but allowed for additional openended comments to ensure that the questionnaire adequately captured the concerns of the community of individuals and organizations involved in Proposition O. Responses were received by August 2006.

\section{Results}

Questionnaire and Interview Results and Issues

We distributed 80 questionnaires, of which 44 were returned, a $55 \%$ return rate. While the total number of returned surveys is not large, the respondents were highly representative of the concerned population. Of the 50 project applicants, $62 \%$ responded to the questionnaire. Two of the three engineering consultants responded. Sixtythree percent of the PRC members responded, and $49 \%$ of the environmental experts. Tables 1,2 and 3 summarize the results of the questionnaires.

\section{Nonprofit Responses}

The discomfiture expressed both in the questionnaire's comment box and in our one-on-one interviews with

Table 1 Nonprofit applicants' survey responses

\begin{tabular}{|c|c|c|c|}
\hline & Good & Fair & Poor \\
\hline Outreach workshops & & $88 \%$ & \\
\hline Project evaluation criteria & & & $75 \%$ of criteria unclear \\
\hline City technical assistance & & & $90 \%$ \\
\hline Interaction with PRC & & & $80 \%$ \\
\hline Process of project evaluation & & & $98 \%$ \\
\hline
\end{tabular}

PRC Project Review Committee

Table 2 Project Review Committee survey responses

\begin{tabular}{ll}
\hline & Score (\%) \\
\hline Scoring and categories ambiguous and inconsistent & 92 \\
Definition of categories and multiple objectives confusing & 75 \\
$\begin{array}{l}\text { Need for nonprofits to present proposals because } \\
\text { inadequate information provided and ambiguous }\end{array}$ & 95 \\
$\begin{array}{l}\text { Need for site visits due to unfamiliarity with NGO- } \\
\text { proposed locations for projects }\end{array}$ & 75 \\
$\begin{array}{l}\text { Insufficient staffing and time to adequately review NGO } \\
\text { proposals and assist NGOs }\end{array}$ & \\
\hline
\end{tabular}

Table 3 Watershed Protection Division-hired engineering consultants' survey responses

\begin{tabular}{|c|c|}
\hline & Score $(n=2)$ \\
\hline \multirow[t]{2}{*}{ Proposition O: a competitive grant program? } & 1: yes \\
\hline & 1: no \\
\hline $\begin{array}{l}\text { City budget sufficient to provide adequate } \\
\text { technical assistance to NGOs? }\end{array}$ & 2: no \\
\hline Criteria utilized by PRC & $\begin{array}{l}\text { 2: they were } \\
\text { adequate }\end{array}$ \\
\hline $\begin{array}{l}\text { Ability to quantify multiple benefits in NGO } \\
\text { proposals }\end{array}$ & $\begin{array}{l}\text { 2: unable to do } \\
\text { so }\end{array}$ \\
\hline Difficulty in assisting NGOs & 2: average \\
\hline Assessment of own expertise in storm water & 2: high \\
\hline
\end{tabular}

PRC Project Review Committee 
nonprofit applicants indicates that they felt misled by the process. The bond language explicitly included public participation in proposing projects, and the city provided funds to help groups develop projects, but project choice using city criteria, and the implementation of chosen projects, remained solely under city control. This was unexpected by the nonprofit applicants, who had expected a chance to publicly and democratically participate in the choice of projects. In addition, a number of the nonprofit applicants believed that they would be eligible for bond money to construct projects. This expectation was due to factors beyond the Los Angeles region. An increasing number of programs that are state funded rely on nonprofit organizations to implement them through a competitive process. Somehow, groups in Los Angeles interpreted the structuring of Proposition $\mathrm{O}$ as being similarly organized, even though the bond did not contain such language. The solicitation process for projects and the assistance offered for project preparation so closely resembled the other bond initiatives that the local groups did not perceive the difference.

The WPD - the city agency responsible for compliance with the CWA and the development and implementation of storm-water pollution abatement projects throughout the city-was on Proposition O's Project Review Committee and also had the responsibility for managing and administering Proposition O. Additionally, it had its own projects competing for the fund. This created an inevitable sense that the department steered the decision making toward projects that met its own internal goals. While the WPD projects were justifiable under Proposition O's purpose to improve storm water, the WPD did not disclose its internal logic of project selection in order for the public to feel it could understand the internal WPD prioritization process for Proposition $\mathrm{O}$ funding. In fact, early on in the process, the WPD introduced the installation of additional catchbasin inserts and covers in high-trash-generating areas to meet trash TMDLs in the project list, with no review by the PRC at all. As a result, a number of environmental nonprofit groups developed the impression that they had to compete unfairly with an unwritten WPD agenda: to finance WPD projects already on the drawing board but for which there had been no funding. While this is difficult to prove, the lack of transparency in the process led many to conclude this outcome.

\section{Engineering Consultants' Response}

The responses by the engineering consultants retained by the city to assist the nonprofits in preparing their proposals, as reported in Table 3, indicate that they felt the criteria developed by the COAC to evaluate projects were inadequate, that the COAC did not have enough expertise to adequately assess multiple-benefits proposals, and that there was inadequate funding to help the nonprofits.

\section{Environmental Experts' Responses}

Questions sent to environmental experts generally reflected a concern that the multiple-benefit criteria developed by the COAC were vague and poorly defined, and that all the water quality improvement criteria should have been combined in one encompassing criterion such as the reduction of pollutant loads. They felt that addressing the pollution problem by individual TMDL was a secondary priority. Answers also reflected a technical orientation toward storm-water remediation, with less value placed on the multiple-benefit and public-participation aspects of the process.

\section{Proposition O Expenditures}

To date, well over $\$ 462$ million has been allocated for those projects approved by the Los Angeles City Council, and almost $\$ 13$ million in projects recommended by the COAC and AOC is pending City Council approval. The nonprofits that had hoped to resubmit in subsequent rounds of funding to improve their proposals were disappointedall the money was allocated in the first round, despite COAC assurances that there would be subsequent rounds.

A number of the projects to repair aging infrastructure and/or fund ongoing programs that, at the same time, had some impact on storm-water and dry-weather runoff were also approved by the COAC. One such program was to replace an old and leaky extensive irrigation system in one of the city parks, justified by the amount of dry-weather runoff and concomitant pollution that would be eliminated. There was a great deal of debate among the members of the COAC about whether such repair projects fulfilled the intent of Proposition O. Some COAC members felt that Proposition $\mathrm{O}$ was city money and could be used for just about any city infrastructure project, and others argued that Proposition $\mathrm{O}$ funds should be used primarily for projects that had direct water quality benefits. For a city where raising taxes requires a two-thirds majority vote, and delinquent in infrastructure maintenance, Proposition $\mathrm{O}$ was an attractive source of funding, and in the end, being able to make needed repairs prevailed.

\section{Discussion: What Lessons for Public Funding Access and Participation?}

New programs and approaches in the policy world of nonpoint source water pollution now often involve multiple stakeholders representing different interests. The 
Chesapeake Bay and Watershed 263 programs of the City of Baltimore, the CALFED Bay-Delta program of California, and watershed and storm-water management in the cities of Portland and Seattle, among others, have created opportunities for greater public involvement through watershed associations, taskforces, collaborative planning, and research and programs. A number of these nonpoint source projects employ multiple-benefit, integrated strategies that include the use of biogenic agents (nature's services) to help treat storm water and to green urban environments (Holden 1971; Nichols and others 1986; Costanza and Greer 1995; Henessey 1997; Liptan and Murase 2002; Heikkila and Gerlak 2005; Richardson 2006).

For example, the Chesapeake Bay Baltimore Watershed 263 initiative included community members in developing its watershed model (Korfmacher 2001), and combines community greening, depaving, tree planting, storm-water trash inserts, and water quality monitoring in a multiplebenefit approach to storm-water remediation. Tree planting and depaving activities are being undertaken by the city in partnership with community-based nonprofit organizations and the effects are being monitored by research scientists to ascertain their actual impacts on water quality outflows (Principal Investigator visit). Initiatives such as these, and others like Great Outdoors Colorado, which fund land use conservation, constitute a new approach to environmental management, a kind of stakeholder democracy of public/ private partnerships with nonprofit organizations that results in the coproduction of programs.

Great Outdoors Colorado was created by a statewide vote designating a portion of lottery revenue for grants for parks, wildlife, outdoor recreation, and open space. A 17member board, appointed by the governor and confirmed by the state senate, governs the board; the grants are competitive, an increasingly common approach, and they require a match of some sort of the group that obtains them (Steelman 2000). The board essentially takes state funds and distributes them to nongovernmental organizations to spend on initiatives approved by the board. The state government is not directly involved in implementing projects. The Clean Water Management Trust Funds in North Carolina and Florida have a similar approach.

Farmland preservation bonds and conservation easements are other examples of the growing set of tools for the environment often developed by the nonprofit sector using state funds or tax incentives, working in collaboration with state agencies to achieve creative ends (Sample 1994; Morrisette 2001; Merelender and others 2004). These programs may be created by entities other than government but rely on at least partial government funding (direct or indirect) to implement and to carry out the programs.
Salamon's (2002) edited volume offers an extensive review of the evolution of public/private cooperation and the rise of what has been termed "governance." Governance, including the coproduction of programs through collaborations and cooperation, has been the response to perceived state failure and the sense that public participation improves environmental management (Fiorino 2006). Not only has public participation been seen to improve environmental management, but the direct involvement in implementing programs by nongovernmental entities, as our examples have shown, has also been instituted in many programs and initiatives.

In addition, Rydin and Pennington (2000) further argue that there are two major reasons for the expanded levels of citizen participation that characterize environmental regulations and programs over the past several decades. One is founded in the democratic right to be involved in the public policy process, and that such participation ensures that decision makers will be better exposed to the values and preferences of society as a whole. Thus policies that involve a wider range of parties are assumed to operate with a greater level of consent and, hence, are more desirable. The other reason, according to Rydin and Pennington, is that greater public participation will assist in producing a better policy outcome (pp. 154-155).

Proposition $\mathrm{O}$ was negotiated by diverse Los Angeles stakeholders responding to the fiscal constraints of a city that requires a supermajority vote to pass bonds or to raise taxes and the imperatives of the CWA. Finding itself out of compliance with CWA TMDLs, and with insufficient general funds to begin to tackle the task, city officials enlisted environmental nonprofits in the writing of Proposition $\mathrm{O}$ and to campaign for the measure's passage.

The language of the proposition created a process in which the public could participate and suggest projects, and it included the goal of multiple-benefit projects. But as it turned out, multiple benefits meant different things to different interests. For the city, the inclusion of multiplebenefit projects translated into flexibility in the use of the bond funds. For environmental nonprofits, multiple use meant the application of solutions that were alternatives to conventional end-of-the-pipe storm-water cleanup, solutions based in the creation of more open spaces, the transformation of hard surfaces into more permeable ones to permit water infiltration, and tree planting for stormwater interception and community benefit.

Governance, the coproduction of programs through collaborations and cooperation, has been the outcome of perceived state failure and the sense that public participation improves environmental management (Fiorino 2006). But often overlooked in this view is that community participation is costly in person-hours and can be unrewarding because the necessary time commitments to participate are 
often uncompensated (Lawrence and Deagen 2001; Irvin and Stansbury 2004). In our case study we found that when such participation is not rewarded either by funding to implement a proposal or by the city itself choosing the nonprofits' proposal and implementing it, the result is a sense of not genuinely being part of the process. Public perception of the bond's implementation, as evinced by the responses to our questionnaires and interviews, was that city government acted as a bureaucratic other, essentially funding its own projects, and the public process was tokenistic. This interpretation, as we have seen, was created by the ambiguity in the proposition's language and exacerbated when city projects "won out" over nonprofit proposals.

Lipsky (1980) points out that government workers are themselves policy tools. Proposition $\mathrm{O}$ is an excellent example of this: the WPD administered the process, framed the information for the COAC and the AOC, presented and recommended its own projects, and is administering the building contracts. At the same time, using the WPD's own logic, it is carrying out its responsibility to comply with federal laws, in this case the mandates of the CWA, and to spend the public's money (the bond) in a way that will achieve knowable, documentable, and reliable results. Yet in this period of skepticism about government, such due diligence, without openness and transparency about the strategy of implementation and inclusive decision making to facilitate the practice of citizenship (Smith and Ingram 2002), leads to disappointed expectations. Government workers are not seen as policy tools; rather they are seen as self-interested implementers of policy.

\section{Beyond Los Angeles}

The obvious California-specific constraints regarding sources of new funding directed at alleviating infrastructure-repair backlog were highly influential in defining the perhaps purposefully ambiguous bond language, which could then be interpreted as needed. While the situation in Los Angeles is a result of decades of underfunding, many cities across the country are-especially with the recent economic downturn-facing fiscal problems in meeting programmatic obligations. States are facing tight budgets, as is the federal government. Process and public perception will be ever more important.

Planning and implementation of infrastructure is a critical part of making cities work. It is expensive, and the way in which it is built and maintained has enormous impacts on the environment. Thus the judicious and thoughtful involvement of the nonprofit sector in programmatic approaches to infrastructure for the coproduction of environmental management in a governance model provides an avenue for much needed new infrastructure, but it needs to be done well.

We propose three generalizable lessons from Proposition $\mathrm{O}$ :

1. The nonprofit sector often does not have the technical capacity to engage in complex urban environmental infrastructure projects. Thus coproduction may not always be possible.

2. It is better for governmental agencies, if they wish to retain control but enlist the support of critical audiences, to be transparent about that desire.

3. The new model of dispersed multiple-benefit projects is not yet well integrated into the old sanitary-city approach, and thus there is an awkward tension between paradigms.

In Los Angeles, Proposition O was a first step toward solving infrastructure problems with a new approach that included multiple benefits and a focus on community participation in developing that new approach. In the end, it promised more than it could deliver, but many lessons were learned.

Acknowledgments The John Randolph Haynes and Dora Haynes Foundation generously funded this study. We also wish to thank Sophie Katz and the anonymous reviewers for their very helpful comments.

Open Access This article is distributed under the terms of the Creative Commons Attribution Noncommercial License which permits any noncommercial use, distribution, and reproduction in any medium, provided the original author(s) and source are credited.

\section{References}

Beierly TC, Konisky DC (2000) Values, conflict, and trust in participatory environmental planning. Journal of Policy Analysis and Management 19(4):587-602

Costanza R, Greer J (1995) The Chesapeake Bay and its watershed: a model for sustainable ecosystem management? In: Gunderson $\mathrm{H}$, Holling CS, Light SS (eds) Barriers and bridges to the renewal of ecosystems and institutions. Columbia University Press, New York, pp 169-213

Fiorino DJ (2006) The new environmental regulation. MIT Press, Cambridge

Heikkila T, Gerlak AK (2005) The formation of large-scale collaborative resource management institutions: clarifying the roles of stakeholders, science, and institutions. Policy Studies Journal 33(4):583-612

Henessey TM (1997) Institutional design for the management of estuarine ecosystems: the Chesapeake Bay. In: Christensen NL, Simpson D (eds) Ecosystem function and human activities: reconciling economic and ecology. Chapman \& Hill, New York, pp 199-223

Higgins K, Roth C (2005) Sun valley park storm-water infiltration basin demonstration project. In: Proceedings of the EWRI world water and environmental resources congress, Anchorage, Alaska 
Holden C (1971) Chesapeake Bay. Science 172(3985):825-827

Irvin RA, Stansbury J (2004) Citizen participation in decisionmaking: is it worth the effort? Public Administration Review 64(1):55-65

Korfmacher KS (2001) The politics of participation in watershed modeling. Environmental Management 27(2):161-176

Lau SL, Khan E, Stenstrom MK (2001) Catch basin inserts to reduce pollution from storm-water. Water Science Technology 44(7): 23-34

Lawrence RL, Deagen DA (2001) Choosing public participation methods for natural resources: a context-specific guide. Society and Natural Resources 14(9):857-872

Lipsky M (1980) Street level bureaucracy: dilemmas of the individual in public service. Russell Sage Foundation, New York

Liptan T, Murase RK (2002) Watergardens as storm-water infrastructure in Portland, Oregon. Chapter 1.6. In: France R (ed) Handbook of water sensitive planning and design. Lewis Publishers, Boca Raton

Los Angeles Bureau of Sanitation (BOS), City of Los Angeles (n.d.) What is storm-water pollution? Available at http://www.lastormwater.org/Siteorg/residents/whatis.htm

Los Angeles County Department of Public Works (LADPW) (2006) Los Angeles County 2005-2006 storm-water monitoring report. LADPW, Los Angeles

Merenlender AM, Huntsinger L, Guthey G, Fairfax SK (2004) Land trusts and conservation easements: who is conserving what for whom? Conservation Biology 18(1):65-75

Morrisette PM (2001) Conservation easements and the public good: preserving the environment on private lands. Natural Resources Journal 41:373-426
Nichols FH, Cloern JE, Luoma SN, Peterson DH (1986) The modification of an estuary. Science 231(4738):567-573

Pincetl S (1999) Transforming California, the political history of land use in the state. Johns Hopkins University Press, Baltimore

Richardson DC (2006) Watershed 263: a resource uncovered. Stormwater September:54-61

Rydin Y, Pennington M (2000) Public participation and local environmental planning: the collective action problem and the potential of social capital. Local Environment 5(2):153-169

Salamon LR (2002) The tools of government: a guide to the new governance. Oxford University Press, New York

Sample A (1994) Building partnerships for ecosystem management on mixed ownership landscapes. Journal of Forestry August: $41-44$

Schrag P (1999) Paradise lost: California's experience, America's future. University of California Press, Berkeley

Shapiro N (2002) Urban runoff: from waste to natural resource. In: Proceedings of 9th international conference on urban drainage (ICUD), Portland, Oregon, USA, 8-13 September 2002

Smith SR, Ingram H (2002) Policy tools and democracy. In: Salamon LM (ed) The tools of government: a guide to the new governance. Oxford University Press, Oxford

Steelman TA (2000) Innovation in land use governance and protection, the case of Great Outdoors Colorado. American Behavioral Scientist 44:580-598

Stenstrom MK (1999) Storm-water impact. Available at http://www. ioe.ucla.edu/publications/report99/storm-water.html. Accessed online 4 May 2007 